时四天連續升溫，由 $9.1^{\circ} \mathrm{C}$ 激升至 $14.9^{\circ} \mathrm{C}$, 而这暴 天的降水合計仅 5.4 毫米。古乡冰川泥石流也有一 些是由降水激发所引起的。如在 1954 年某月該区 記录的气溫較 3 日前降低了 $2-3^{\circ} \mathrm{C}$ ，維持在 $12-$ $13^{\circ} \mathrm{C}$ 間，但降雨量每天达 $13-23$ 毫米,这几天的泥 石流都在上午 8 - 10 时爆发，很显然，这里降雨起 了主要作用。泥石流在爆发前夕有一个能量的积翼 过程, 实际天气变化与泥石流的关系要比上述例子 复杂得多。

古乡毗邻地区某些較小的泥石流，可能主要是
四雨引起的。例如忠垻泥石流，1963 年有两天連續 暴雨，但沟有升溫晲象，而在后一日猛烈爆发，泥 石流泛监于高出河床 3 米的阶地上，冲出的最大石 块的体积約 30 公方，重約 78 頓。

如何防止泥石流是一項比較复杂的科学技术間 題。为了进一步了解西藏泥石流形成的具体条件和 水交性质及活动規律，中国科学院地理研究所冰川 冻土研究室与西藏自治区筹委会有关单位合作，准 备組織泥石流的綜合考察与定位覌測，以便針对該 地区泥石流的特点，提出防治措施。

\title{
长江中、下游新的有关冰川遺迹的記录
}

\author{
黃第藩楊世倬
}

（中国科学院兰州地盾游究所）

1963 年六、七月間，笔者偕刘中庆、梅震亚 两同志进行了长江中、下游第四紀冰川現像的考 察，茲将录記所得，簡报如下。

\section{一 一种新的冰川条痕砾石}

关于漂破摩擦面上所带条痕的报导，迄今只有 一种。这种条痕的主要特征是: 近似釘形, 影响仅 及于砾块表面, 大多是直綫式細槽, 但也有的微微 弯曲, 其形态显梁在冰川中被刻划而成。这次我們 在芦山高壠至白石咀公路旁，于野猫缅北段、谷山 湖畔，看到在数块道径 1 米上下的漂砾的磨 光面 上，有一种特殊的表面构造，也就是有許多环状条 痕, 随面起伏, 趗至滿布表面。这些漂砾属大姑冰 期的第一、第二道前磧，均由坚硬的石英砂岩所組 成，完整无战，而稜角皆已強去，有的带有隦得十 分光滑的出面和深刻的斑痕。其上环状条痕的特点 (图 1 ) 是: 近于圆形或椭圆形, 直径一般为 4-6 厘米，但不封闒，弧綫长度大多是周长的 $2 / 3$ 左 右，而且常可見 $1 \sim 2$ 处微有轉折，有如两三段弧
綫彼此連接而成。条痕成弧釘状，具有釘形条痕的 基本特点，始端槽深且寛，最深可达 3 毫米左右， 向末端逐漸地或突然地变浅变窄，在有些这种条䟵 的末端还带有由 $2 \sim 3$ 条极細而收聚的划痕所 組 成 的星部。副槽的內壁本整，外壁作不規則的 鋸 齿 状，橫切面呈 $\mathrm{V}$ 字形，有如石匠刻銼而成，其受力 的一面悉被率平，而另一面則是崩落所致。在同一 砾块上，所有条痕自始至末，均向同一方向拉轉， 构成一組(很可能覌察上有局限性)。

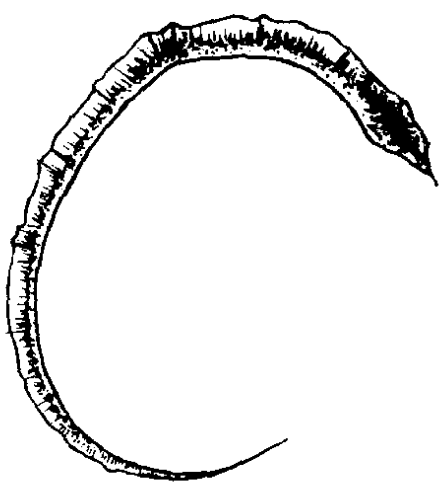

图 1 漂破环状条浪素描 
无論是从这些环状条痕所在砾块的形态特征 上,或是从其本身的形态性稹上来看,它們都只能是 在冰川作用下产生的。可以設想，这些漂砗會被䣄 于冰川底部, 当冰川带着它們刨括冰佅（冰川的基 底)的时候, 被阻于某处坚硬而参差不平的冰床(不 是冰床上可灙动的石砾) 之上，引起了冰流对 砾 块 的不均衡的压力和推动力（条痕刻槽两面特性的不 同郎可証明)，致使石块在原地发生轉动。在冰川 的强大压力下，石块本身就被崎岖、粗䊁而带有許 多小尖鋒的冰床，刻划出特殊的环状条痕。与此同 时，冰床本身也逐淔被研磨而变平，砾块上的刻䄚 也随之变浅，以至分裂、消失。自然，笔者也不排 斥被裹于冰川中的石块，彼此相互既挤而造成上述 环状条痕的可能性(同样是因冰的压力)。

这种环状条痕的特征，排除了其本身任何构造 成因或流水成因的可能性。因此，具有这种条痕的 砾石是庐山地区第四紀冰川的可靠証据之一。我們 建議把它命名为李四光环痕。可惜, 由于当日阴 雨, 未获清斨的照片。
湖西部湖滨平原、邱陵地带, 有冰川漂砾分布的綫 索，我們进一步看到了一些与第四紀冰川作用有关 的現缘。其中最引人注意的是, 在漕水下游津市南 側有巨厚的冰川泥砾分布。

津市隔漕水对岸有一座黃姑山，窑立于荆汇四 口与澧水三角洲冲积平原的西 南 側，海 拔 200 余 米, 高出水面約 180 米; 北坡山势陡峻, 洔 水 西 来, 值逼山麓, 抹轉折南流。黃姑山与其南側的其 他一些低山共同組成了一道向南南西起伏延展、逐

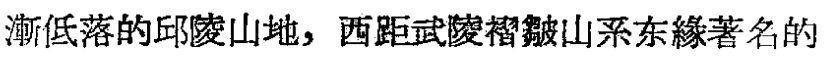
大断裂綫达 30 余公里。它們之間为邱陵、本原所 阻隔。其中以大致成南北向的古老山为最高, 海拔 $250 \sim 280$ 米, 主要由坚硬的泥盆紀砂岩所組成, 与 黄姑山邱陵間隔一开閐的洼地, 遙相对峙(图 2)。

在黄姑山北麓, 有一块不大的灰岩夹紫紅色泥 岩出露；高約 15 米，喀斯特化現象明显，属 奧 陶 紀。值得注意的是，灰䇹中有許多水平的或向西緩 傾的小断面，其上擦痕累累，显系某种巨大水平力 自西向东推复所致。另外, 我們还注意到, 这种擦 痕面却未會受到喀斯特化的影响。故灰岩的喀斯特 化在前, 而断面擦痕的产生在后。除这块露头之 外，整个黄姑山从山麓遖达山頂皆由粘勏的棕紅色 泥砾所构成; 南延的其他印陵山地, 或为紅泥复 盖, 或亦有泥砗分布。山上較大而完整的砾块几乎 被尽数搬走，成了山下許多建筑中不可缺少的材 料。

我們确定黄姑山第四紀堆积层应属冰川泥砾的
剩蝕残山或武陵山系东緣山岭

(均由古生界組成)

1.黃姑山海拔 210 -250 米

2.古老山 海拔 250 - 280 米

\section{二 洞庭湖西部湖滨平原上的冰川泥砗}

浪据湖南省地盾局石油普查队等提供的在洞庭

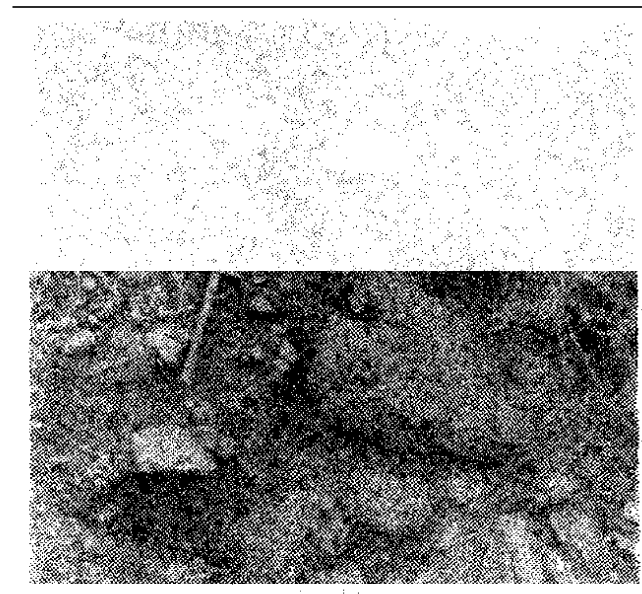

崏片 1 黃姑山山腰烸拔 80 米左右所 看到的水川泥砾 
原由, 是依据以下的几点訩識:

（1）它的岩性特征是: 大小悬殊、杂乱无音、 排列无序的石块和砾石, 与粘郼的紅泥掕混, 毫无 层序(照片 1、2)。其中所含的較大的砗块，隻是“掉 落”在泥、砂、細在砾組成的混合沉积物中，横趟、 倒立、斜列者各处均可同时見及。我們筧避山搜 寻, 在堆积物中没有看到任何水成沉积所特有的沉 积結构, 如科寻理、交錯层等。这些特征就使它有 別于河流相或洪积相的堆积物。
照片 3 示漂砾的稜角已經蝕去, 而仍显 固有之形象(鉭长 36 厘米, 地点同照片 1)

照片 2 黄姑山山頂海拔 200 米处所 看到的冰川泥砗

（2）它的砾块几全部由石英砂岩所組成，主要 应取材于西側的武陵山区的泥盈系，最大砗径（包 括在山頂所見者)可这一米。其中較小的砾块棱角 显著, 而直径在 20 厘米以上的, 大抵稜角皆已消 失, 有的魔圆度較高(照片 $1 、 2$ ), 有的仍显示出圆 有的形象(照片 3 )。这些特征与上麓堆积相全然不 同，更何况黃姑山抹非地处山篦。另外，在部分石 块_上还可以看到若干条痕，显柔在冰流中被刻划而 成。由于砾块大多已被搬走, 故条痕砑石不可多得。

（3）我們算在洞庭湖四周許多地区作过第四紀 地层的覌察，不諭是第四紀下部的泪罗組 $\left(Q_{I}\right)$, 还是中部著名的白砂井組 $\left(\mathrm{Q}_{\mathrm{II}}\right)$ 等, 其沉积特征, 均与黄姑山的第四紀堆积不同（照片 4、5）。泪罗 組下部是砗石层(牛胶結), 科层理发育, 上部是砂 与粘土間互, 水平层理清晰; 白砂井組下部是分选 良好的砾石层, 具科层理, 上部是网紋紅士。

（4）从黄姑山第四紀堆积的整个性状来看, 与 
外，黃姑山第四紀堆积的砗块組成，其久經风化而 支离破碎的面貌明显可見，亦說明它的形成时代， 应早于庐山冰期。

（5）从图 1 中可以看出，黃姑山的北面与东面 是一片广闊的湖滨本原, 而南面与西 面 近 40 公里 的范围网也仅有一些与黃姑山大致在同一級高度的 剝蝕残山(基本定型于第四紀之初)斯布于湖滨平原 之上, 橫互于武陵山系之前。这就使得坡积之說无 以成立。假如黄姑山第四紀堆积非冰川作用而成， 那么碩大的石块如何能超越重重障碍, 且梯山而 上!?

（6）上迅黄姑山下，奧陶紀灰岩中的許多断面 擦痕，应源于自西而东的水平推力，恰为冰流之說 的位証。

綜上所述，我們訩为黄姑山第四紀堆积非冰川 搬运无以形成，它应属冰川沱砗。

綜观我国东部已发現的冰川泥砗层，一般厴度 仅十余米，最厚亦不过数十・米; 离山麓最沅也很少 超过十余公里。但黄姑山的泥砾层, 其厚度估計在 100 米左右; 远离山麓則达 30 余公里。关于泥研 层厚度的估計，我們是这样考虑的：黃始山相对高 差泣 180 米，山势頗为陡峻，除北麓有一小块奧陶 系的露头之外, 从山頂直到山麓均为泥砾盖复, 在 割切的沟谷中亦无基岩裸露。因此，我們訩为，郎 使考虑到可能存在的基岩起伏的影响，泥砾层的厚 度世似乎不宜作过小的估計。

这一泥砾层的发現, 实非完全出于意料, 但其 厚度之大、海拔很低而又分布之远，却殊为架見。 可以預期, 它将会在我国第四紀冰川学的硎究中占 有较重要的位置。

在洞庭湖湖区西部、大断裂以东的地区，自西 而东，首先是第三系紅色邱陵区，平緩起伏，构成 波状地表; 再岽，有中更新世白砂井組*組成 的阶 状邱陵, 两級分別离出当地水淮面約 25 米和 50 米 的阶地，广泛分布，保存完好。黃姑山泥砾层是分 布在更东的地区。有意义的是, 該山存在有与前相 应的阶地, 所不同的地方是这些阶地系泥砾遭受后 期侵能而形成的。这些都說明造成黄姑水磧的这一
次极为巨大的冰流，可能是发生在更新世早期。在 这次冰川消退的过程中所遺留的漂砗等，尽管絕大 部分已被后期侵創所冲毁，沉积所掩埋，但至今仍 有迹可寻。其中，如临澧西南 4 公里处有一块突出 在平原上的孤石一一当地叫“烏龟石”（长10 米、寛 6 米、高 4 米，据湖南省地稹局資料)，郎为例証 之一。

看来，除这一个冰期以外，本区还发生过其他 冰期, 次数不詳, 有待研究。据湖南省地稹局石油 普査队的資料分析, 在阶状邱陵的西緣, 第三系紅 色邱陵区的东側，也有泥砾分布。如澧县西北的张 家厂一带。另外，在第三系紅色邱陵区的范围內， 我們发現有保存十分完好的冰蝕地形。如桃源县西 南翊家溪(鎭)北面的分水均U形谷(图 3 )。这个冰 川槽谷, 迄今保存良好, 是由第三系上部坚硬的暗

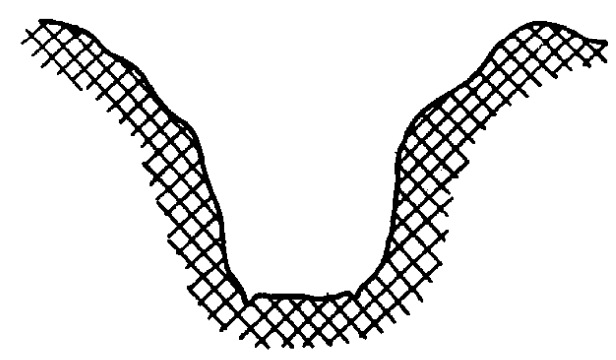

图 3 水分均U 形谷橫部面

紫紅色砾岩和砂岩組成, 谷坡壁立(玤无断晨), 谷 底平坦, 向南南东方向直駛, 谷中冰坎犹存（郎分 水㘬所在)，两旁的排水槽仍在(西边的已被水流所 放弃)，谷口因冰川䓂割而形成的三角面，历历可 睹。以上这些实事, 可能代表 $I \sim 2$ 次較新的 冰 期。

根据以上所有情况来看, 我們覚得本区冰川現 象的地貌分布，与李四光教授等于 1940 年在 鄂 西 恩揓盈地所看到的情景, 頗为类似。有理由相信, 本区的冰川現管在将来經过詳細研究以后，对我国 冰期的划分和古地理的再造等，一定会提供出許多 很有意义的資料。

\footnotetext{
*关于白秒井組的时代問題，本交中无法詳述。
} 